\title{
Human Capital in Sustainable Development and Macro-level Criteria
}

\author{
Victor Medennikov ${ }^{1, *}$, Tatiana Kokuytseva ${ }^{2}$, and Oksana Ovchinnikova ${ }^{2}$ \\ ${ }^{1}$ Computing Center of the Federal Information Center "Informatics and Management" RAS, Vavilov \\ st. 40, 119333 Moscow, Russia \\ ${ }^{2}$ People's Friendship University of Russia (RUDN University), 6 Miklukho-Maklaya Str., Moscow, \\ 117198, Russian Federation
}

\begin{abstract}
In the light of the ongoing digital transformation in the world, there has been a significant increase in scientific and practical interest in the problem of human capital (HC) in recent years. This interest bases on the understanding of its key role in the socio-economic life and development of society with a radical change in the technological order at all its hierarchical levels: national, industry, regional, corporate and individual. On the upper levels (national, sectoral, regional) $\mathrm{HC}$ is characterized by demographic indicators, characteristics of the level and quality of education, health, living standards, cultural development, degree of scientific and technological scope of the society, degree of mobility when moving from areas with relatively low standard of living in places with higher, etc. The paper proposes a powerful evaluating tool for improving and increasing the human capital measurement, which can serve for increasing the social welfare of society, and transferring the most effective innovative solutions to the economy. The tool is based on mathematical modelling and correlations among $\mathrm{HC}$ and non-HC variables.
\end{abstract}

\section{Introduction}

In the light of the ongoing digital transformation in the world, there has been a significant increase in scientific and practical interest in the problem of human capital (HC) in recent years. This interest bases on the understanding of its key role in the socio-economic life and development of society with a radical change in the technological order at all its hierarchical levels: national, industry, regional, corporate and individual. On the upper levels (national, sectoral, regional) $\mathrm{HC}$ is characterized by demographic indicators, characteristics of the level and quality of education, health, living standards, cultural development, degree of scientific and technological scope of the society, degree of mobility when moving from areas with relatively low standard of living in places with higher, etc. At the firm level, the HC reflects the professional abilities of employees, the degree of realization of their educational and cultural potential, and the state of health. At the level of an individual, HC is a person's

\footnotetext{
*Corresponding author: dommed@mail.ru
} 
accumulated knowledge and skills, life experience in the different branches of activities, which help to realize his or her abilities and acquire the revenue from own basis.

\subsection{Justification of the system of criteria for evaluating human capital at the macro level}

According to the analysis of the system of factors that have the greatest impact on the quality of human capital assessment at the macro level and the concept of unified information Internet space for scientific and educational resources (EIIPNOR) with potential, still unrecognized, Internet technologies, it becomes urgent to develop a methodology for assessing human capital at the macro level. Basis should be newly discovered new qualities of ICT. To do this, it is necessary to include the most important indicators of the activity of educational institutions that affect the quality of human capital by achieving goals in the appropriate assessment criterion. Those are training highly qualified specialists and scientists, conducting scientific research with the design of their products in a generally accepted format, which should also lead to an increase in human capital.

\section{Materials and method}

The effectiveness of achieving these goals is influenced by many other factors, in addition to the EIIPNOR indicators. For example, these are the level of training of applicants, their motivation to acquire knowledge, the situation of science itself and the environment for its implementation, financial and moral aspects in the form of the prestige of the work of scientists, professional literacy of the management of the Ministry of Education and Science and line ministries. Also these are the state of the "social order" of society and the country's economy for the profile of training specialists; the amount of funding for educational institutions. However, all these qualitative indicators are rather difficult to confirm by numerical data, especially by functional mathematical dependencies.

In this case, as a general criterion of the methodology, we will take the effectiveness of the use of informational scientific and educational resources (INOR) of educational institutions represented in the Internet space. The integral criterion should take into account the data from the self-examination report, according to the basic requirements of the Ministry of Education and Science, Rosobrnadzor to the content of the websites of educational institutions, the degree of demand for INOR in society and the economy, the degree of influence on the quality of teaching and training of highly qualified specialists and scientists in them. As noted in the initial sections of the work, there is a need for reflection in the methodology and assessment of sites using sitemetric methods that take into account the image and reputation of educational institutions. An analysis of the sites of industrial and educational institutions made it possible to identify new trends in the provision of services in the Internet space in the form of all kinds of electronic trading platforms and labor exchanges. It is obvious that these information services, as follows from the modern understanding of $\mathrm{HC}$, also have an impact on the growth of human capital. The choice of distance learning and retraining as a particular criterion included in the integral criterion of the method is obvious, as well as the possibility of obtaining qualified advice on the issues of interest, which is extremely important with a significant change in the entire technological order in the world. The need to take into account in the methodology the degree of use of applied software and databases and their quality are justified in the basic principles of assessing human capital [1].

Information resources (IR) included in the requirements of the Ministry of Education and Science, Rosobrnadzor, and having the greatest impact on the attainability of the goals of 
universities, we will call secondary information educational resources (VIOR). Indicators from the EIIPNOR list, reflecting information on seven types of INOR: developments, publications, consulting activities in the form of the number of consultants in a particular area of knowledge, regulatory information, distance learning, applied software packages, databases are called primary information scientific and educational resources (PINOR).

The ontological classification of INOR is associated with modern trends and capabilities of Internet technologies, when Internet service providers provide those for storing and processing site content in structured databases controlled by powerful database management systems (DBMS). The database content can be stored both in the form of an information catalog and in the form of a full-format presentation. We will call this a form of IR storage. On the other hand, the storage of site content not in a DBMS, as it happens in most cases now, is called an unordered view. When stored in a DBMS, it is an ordered presentation with the ability to navigate, for example, based on the SRSTI topic, by organization, industry and region, by authors and their qualifications, by keywords, etc. We will call this the level of IR integration.

Such an ontological standardization of the presentation of information resources in EIIPNOR makes it possible to develop an independent methodology for assessing human capital at the macro level, as well as a methodology for a comprehensive assessment of all the activities of educational institutions. With the introduction of standard sites in universities, the assessment technique becomes automated and low-cost.

This assessment method, in particular, when included in indicators of regional development, will also reflect the degree of readiness of educational institutions to influence regional digital transformation. Standardization of the presentation of IR under certain conditions leads to a unified assessment methodology $[2,3,4,5,6]$.

In this case, the efficiency of using information scientific and educational resources for assessing human capital is understood, based on the theory of operations research methods, the effectiveness in achieving a certain goal. To assess the HC on the basis of the announced methodology, we will single out the following as the goal of forming the EIIPNOR:

- relevance, completeness, objectivity, reliability, and consistency of the collected and stored information;

- adequacy, efficiency, comfort and ease of searching and obtaining the necessary information;

- a variety of tools for implementing different modes of information processing in the form of statistical methods, mathematical modeling, big data, artificial intelligence;

- comprehensibility, availability of data for a wide range of users (potential applicants undergoing training and retraining, teaching staff, government officials, business representatives, scientists, all segments of the population, etc.).

\subsection{Mathematical model of the methodology for assessing human capital at the macro level}

Let us formalize both the verbal description of the system of factors that most affect the quality of human capital assessment, and the system of criteria for assessing human capital at the macro level. The first version of the foundations of the methodology is given in [7], significantly modified in this work specifically for the purpose of assessing human capital. For a mathematical description of the technique, we introduce the following expressions.

$\mathrm{i}$ - PINOR integration level code, $i \in I$;

$l-$ PINOR form of storage code, $l \in L$;

$n-$ PINOR specification code, $n \in N$;

$\mathrm{m}$ - educational office number, $m \in M$; 
$\mathrm{h}-$ VIOR representation code, $h \in H$;

$\mathrm{t}$ - time moments of calculations (during EIIPNOR realization the computation can be done in every moment);

$P_{j}^{t m}$ — partial criterium of HC estimation by the efficiency of IR use of m-th High School by $\mathrm{j}$-th indicator at moment $\mathrm{t}, j \in J$;

$P^{t m}$ - general criterium of HC estimation by the efficiency of IR use of $m$-th High School at moment t;

$\alpha_{i}^{1}$ - weigh coefficient of the integration level of PINOR;

$\alpha_{l}^{2}$ - weigh coefficient $l$-th form of storage of PINOR;

$\alpha_{n}^{3}$ - weigh coefficient of $\mathrm{n}$-th specification of PINOR representation;

$\beta_{j}$ - weigh coefficient of partial criterium of HC estimation of the efficiency of PINOR use by $\mathrm{j}$-th indicator;

$v_{i \ln 0}^{t m}$ - volume characteristic of PINOR of i-th integration level of 1-th form of storage, $\mathrm{n}$-th representation form on the level of $\mathrm{m}$-th High School at moment $\mathrm{t}$;

$v f_{i \ln f}^{t m}$ - volume characteristic of PINOR of i-th integration level of 1-th form of storage, $\mathrm{n}$ - th representation form on the level of $\mathrm{f}$-th faculty of $\mathrm{m}$-th High School at moment $\mathrm{t}$

$v k_{i \ln k}^{t m}$ - volume characteristic of PINOR of i-th integration level, 1-th form of storage of $\mathrm{P}, \mathrm{n}$-th representation form on the level of $\mathrm{k}$-th department of $\mathrm{m}$-th High School at moment $\mathrm{t}$;

$\lambda_{i l n}^{t m}$ - the level of PINOR estimation of $\mathrm{i}$-th integration level, 1-th form of storage, $\mathrm{n}-\mathrm{th}$ representation form of $\mathrm{m}$-th High School at moment $\mathrm{t}$;

$\lambda_{i l n}^{t m}=\left(v_{i \ln 0}^{t m}+\sum_{f} v f_{i \ln f}^{t m}+\sum_{k} v k_{i \ln k}^{t m}\right) / \max _{m}\left(v_{i \ln 0}^{t m}+\sum_{f} v f_{i \ln f}^{t m}+\sum_{k} v k_{i \ln k}^{t m}\right)$;

$d_{r m}^{t 2}$ - volume characteristic of $r$-th indicator of partial criterium of HC evaluation by sitemetric methods в m-th High School at moment t, $r \in R$;

$q_{r m}^{t 2}$ - volume characteristic of r-th criterium of partial criterium of $\mathrm{HC}$ evaluation by sitemetric methods в m-th High School at moment t;

$\omega_{r}^{2}$ - weight coefficient of $r$-th indicator of partial criterium of $\mathrm{HC}$ evaluation by sitemetric methods;

$q_{r m}^{t 2}=d_{r m}^{t 2} / \max _{m}^{t 2} d_{r m}$

$d_{s m}^{t 3}$ - volume characteristic of s-th indicator of partial criterium of HC evaluation by the conditions of ETP in m-th High School in moment $t$;

$\omega_{s}^{3}$ - weigh coefficient s-th indicator of partial criterium of $\mathrm{HC}$ evaluation by the conditions of ETP;

$d_{g m}^{t 4}$ - volume characteristic of g-th indicator of partial criterium of $\mathrm{HC}$ evaluation by the conditions of EBT in m-th High School in moment $t$;

$\omega_{g}^{4}$ - weigh coefficient of g-th indicator of partial criterium of $\mathrm{HC}$ evaluation by the conditions of EBT, $g \in G$;

$d_{h m}^{t 5}$ - volume characteristic of h-th indicator of partial criterium of HC evaluation by the conditions of VIOR in $\mathrm{m}$-th High School in moment $\mathrm{t}, k \in K$;

$q_{h m}^{t 5}$ - volume characteristic of h-th indicator of partial criterium of $\mathrm{HC}$ evaluation by the conditions of VIOR in m-th High School in moment $t$;

$\omega_{h m}^{5}$ - weigh coefficient h-th indicator of partial criterium of $\mathrm{HC}$ evaluation by the conditions of VIOR in m-th High School, $k \in K$;

$q_{h m}^{t 5}=d_{h m}^{t 5} / \max _{m} d_{h m}^{t 5}$

So, we obtain: $P^{t m}=\sum_{j} \quad \beta_{j} \cdot P_{j}^{t m}$, where $P_{1}^{t m}=\sum_{i, l, n}^{\sum} \lambda_{i l n}^{t m_{i}^{1^{2^{3}}}}, P_{2}^{t m}=\sum_{k} \omega_{k}^{2} q_{k m}^{t 2}$, 


$$
P_{3}^{t m}=\sum_{s} \omega_{s}^{3} d_{g m}^{t 3}, P_{4}^{t m}=\sum_{g} \omega_{g}^{4} d_{g m}^{t 4}, P_{5}^{t m}=\sum_{h} \omega_{h}^{5} q_{h m}^{t 5}
$$

The weight coefficients of the characteristics of the criterion for assessing human capital according to the types of VIOR presentation should be determined on the basis of a large set of various means mentioned above: expert assessment; analysis of the verbal opinions of experts in the field of education quality assessment, reflected in the relevant articles. Methods for calculating assessments of the activities of educational institutions on the basis of their rating, with the exception of a questionnaire of teachers, failed. However, we will try to find these weight coefficients using several other methods.

\subsubsection{Method of obtaining weights characteristics based on functional analysis}

Let it be:

$\mathrm{m}$ - High school number, $m \in M$;

$\mathrm{h}$ - number of a characteristic indicator of $\mathrm{HC}$ estimation by the VIOR representation forms, $h \in H$;

$r_{0 m}-\mathrm{HC}$ estimation by the PINOR representation of m-th High School, $r_{0 m} \in R_{0}$;

$r_{m h}$ - characteristic estimation of h-th VIOR of m-th High School;

$s_{h}$ - correlation coefficient between $r_{0 m}$ and $r_{m h}$;

$\bar{s}_{h}=s_{h} / \sum s_{h}$ - normed correlation coefficient between $r_{0 m}$ and $r_{m h}$;

In this case the variable $\omega_{h m}^{5}$, defining the weight of h-th characteristic VIOR indicator of m-th High School, is equal to $\bar{s}_{h}$.

\subsubsection{Method of obtaining weights of VIOR characteristic indicator according to the Kendall concordation coefficient}

Let it be:

$\mathrm{m}$ - High school number, $m \in M$;

$\mathrm{h}$ - number of a characteristic indicator of $\mathrm{HC}$ estimation by the VIOR representation forms, $h \in H$;

$r_{0 m}-\mathrm{HC}$ estimation by the PINOR representation of m-th High School, $r_{0 m} \in R_{0}$;

$r_{m h}$ - characteristic estimation of h-th VIOR of m-th High School;

$k_{h}$ - Kendall concordation coefficient for $r_{0 m}$ and $r_{m h}$;

$\bar{k}_{h}=k_{h} / \sum k_{h}$ - normed concordation coefficient.

In this case the number $\omega_{h m}^{5}$, defining the weight of h-th VIOR characteristic number of m-th High School, is named $\bar{k}_{h}$.

\subsubsection{Method for determining the weights of the characteristic indicator of VIOR based on a probabilistic estimation model}

To apply this method, we will follow the works $[8,9]$.

When using this method, it is assumed that there are some "true" estimates of the studied indicators, and expert estimates randomly deviate from the "true" estimates, while these deviations are a realization of a random variable with a mathematical expectation equal to the "true" estimate.

It is also assumed that these random variables are distributed in accordance with the normal law. In this case, the probability that the given random variable is not higher than $\mathrm{x}$ equals $F(x)=\Phi\left(\frac{\mathrm{x}-\mathrm{x}_{i}}{\sigma_{i}}\right)$, where $\mathrm{xi}$ - expected value of the $\mathrm{i}$-th indicator, $\sigma_{i}^{2}$-dispersion of $\mathrm{i}$ - 
th indicator, and $\Phi(u)=\frac{1}{\sqrt{2 \pi}} \int_{-\infty}^{u} e^{-\frac{z^{2}}{2}} d z$ is a function of normal distribution with expected value 0 and dispersion equal to 1 .

In this method we will consider $\sigma_{1}=\sigma_{2}=\ldots=\sigma_{N}=\sigma$.

In this case, the probability that expert will estimate i more than $\mathrm{j}$, is $\Phi\left(\frac{x_{i} \mathrm{x}_{j}}{\sigma}\right)$.

Then, if cij are given and reflect that $\mathrm{i}$ is better than $\mathrm{j}$, we have the system of equations for finding all xi estimations:

$$
c_{i j}=\Phi\left(\frac{x_{i-x}}{\sigma}\right)
$$

If we denote as dij those sole values, which give $c_{i j}=\Phi\left(d_{\mathrm{ij}}\right)$, then, due to monotonicity of $\Phi()$, we will get the system of equations $x_{i}-x_{j}=\sigma d_{i j}$.

Considering $\sigma=1$, and adding all dij by $\mathrm{j}$ and dividing by total $\mathrm{N}$, we can conclude, that $\frac{1}{N} \sum_{j=1}^{N} d_{i j}$ defines «true» values $\mathrm{xi}$, but the expert estimations will be defined as $\Phi\left(\frac{1}{N} \sum_{j=1}^{N} d_{i j}\right)$.

Let it be:

$\mathrm{m}$ - High school number, $m \in M$;

$\mathrm{h}$ - number of a characteristic indicator of $\mathrm{HC}$ estimation by the VIOR representation forms, $h \in H$;

$r_{0 m}-\mathrm{HC}$ estimation by the PINOR representation of m-th High School, $r_{0 m} \in R_{0}$;

$r_{m h}$ - characteristic number of h-th VIOR m-th High School;

$r_{m i j}{ }^{+}-$number of characteristics of vector $\{\mathrm{r} 1 \mathrm{i}, \mathrm{r} 2 \mathrm{i}, \ldots, \mathrm{rMi}\}$, which values becomes bigger than corresponding characteristics of vector $\{\mathrm{r} 1 \mathrm{j}, \mathrm{r} 2 \mathrm{j}, \ldots, \mathrm{rMj}\}$;

$r_{m i j}{ }^{-}$- number of characteristics of vector $\{\mathrm{r} 1 \mathrm{i}, \mathrm{r} 2 \mathrm{i}, \ldots, \mathrm{rMi}\}$, which values are lesser than corresponding characteristics of vector $\{\mathrm{r} 1 \mathrm{j}, \mathrm{r} 2 \mathrm{j}, \ldots, \mathrm{rMj}\}$;

$r_{m i j}=-$ number of characteristics of vector $\{\mathrm{r} 1 \mathrm{i}, \mathrm{r} 2 \mathrm{i}, \ldots, \mathrm{rMi}\}$, which are equal to $\{\mathrm{r} 1 \mathrm{j}, \mathrm{r} 2 \mathrm{j}, \ldots, \mathrm{rMj}\}$.

The estimations of cij, that give the probability, that $\mathrm{i}$ better than $\mathrm{j}$ are $\left(r_{m i j}{ }^{+}+0,5\right.$. $\left.r_{m j}^{=}\right) / M$ for cij and for cji.

\subsubsection{Method for determining the weights of the characteristic indicator of VIOR based on the competence matrix estimation}

Let it be:

$\mathrm{m}$ - High school number, $m \in M$;

$\mathrm{h}$ - number of a characteristic indicator of $\mathrm{HC}$ estimation by the VIOR representation forms, $h \in H$;

$r_{m h}$ - characteristic estimation of h-th VIOR of m-th High School;

In this case for a given matrix $\mathrm{R}=\{\mathrm{rmh}\}$ ( size $\mathrm{M}^{*} \mathrm{H}$ ) those vectors are computed iteratively:

$$
r^{t}=\frac{1}{\lambda^{t}} R \cdot R^{\prime} r^{t-1}, q^{t}=\frac{1}{\lambda^{t}} R^{\prime} \cdot R q^{t-1}
$$

where the dash symbol indicates the transposed matrix to the matrix R, expressed by the matrix elements.

Under the condition of "indecomposability" of the matrix $\mathrm{R}$, the condition of which is satisfied in our case, the iterations converge rather quickly to some limit vectors and, where $\mathrm{q}$ is the eigenvector of the maximum eigenvalue of the matrix. 
In this case, equality is fulfilled, which leads to group estimates of $r$ assessment indicators equal to the individual estimates of experts $\mathrm{R}$ on the basis of weighing them with the calculated competency coefficients q.

In this case, the value that determines the weight of the h-th characteristic indicator of the VIOR of the $\mathrm{m}$-th educational institution is taken equal to the $\mathrm{h}$-th indicator of the found limit vector.

Now it is already possible to renormalize the column vectors $\mathrm{Rj}$, each of which defines a group of expert evaluations $\mathrm{j}$ of the evaluation indicators of the matrix $\mathrm{R}$, as a result of which the zero value of the expert scale will move to the point of the arithmetic mean, and the variance after dividing the arithmetic mean by the standard deviation of this vector will be equal to 1 . With such an operation, the product will be the matrix of the correlation coefficients of the vectors $\mathrm{Rj}$, and the maximum eigenvalue turns into the variance of the principal factor q.

The presented method reflects one of the approaches of the theory of quantitative factor analysis.

\section{Results of calculations by methods of mathematical statistics of weights of characteristics of criteria for assessing human capital}

On the basis of the presented four methods of mathematical statistics and expert (based on the opinions of university teachers) determination of the weights of the characteristics of the private criterion for assessing human capital by types of presentation of VIOR, general assessments of the $\mathrm{HC}$ of universities were obtained, as well as general ratings of agricultural universities (Table 1), the results of which showed high consistency of all ratings, giving a wide scope for further use of any of the considered methods, depending on the availability of information, as well as combinations of them, for example, average ratings and ratings. Due to the further use of the method of calculating Kendall's concordance coefficient to establish a relationship between the ratings of universities with regional ratings, we will use this method, respectively, the data from the column obtained by this method (Table 1). In tab. 1 the structure of the information is presented as (overall rating / rating).

Table 1. General estimations of $\mathrm{HC}$ and High School ratings.

\begin{tabular}{|c|c|c|c|c|c|c|}
\hline High school & 泀 & 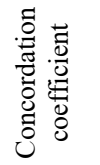 & 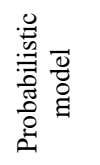 & 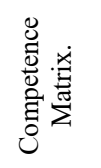 & 离 & 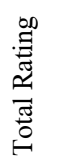 \\
\hline $\begin{array}{l}\text { Kuban State Agrarian } \\
\text { University }\end{array}$ & $42.10 / 1$ & $36.89 / 1$ & $37.12 / 1$ & $37.22 / 1$ & $44.76 / 1$ & 1 \\
\hline Orel State Agrarian University & $39.41 / 2$ & $34.41 / 2$ & $34.24 / 2$ & $34.22 / 2$ & $33.22 / 2$ & 2 \\
\hline $\begin{array}{l}\text { Krasnoyarsk State Agrarian } \\
\text { University }\end{array}$ & $31.31 / 4$ & $31.42 / 3$ & $31.22 / 3$ & $31.44 / 3$ & $29.48 / 3$ & 3 \\
\hline $\begin{array}{l}\text { RSAU-Moscow Agricultural } \\
\text { Academy }\end{array}$ & $37.62 / 3$ & $28.31 / 4$ & $28.31 / 4$ & $28.29 / 4$ & $28.34 / 4$ & 4 \\
\hline $\begin{array}{l}\text { Kemerovo State Agrarian } \\
\text { University }\end{array}$ & $28.84 / 5$ & $26.81 / 5$ & $26.89 / 5$ & $26.87 / 5$ & $27.46 / 5$ & 5 \\
\hline $\begin{array}{l}\text { Belgorod State Agrarian } \\
\text { University }\end{array}$ & $28.79 / 6$ & $26.69 / 6$ & $26.77 / 6$ & $26.64 / 6$ & $23.24 / 6$ & 6 \\
\hline $\begin{array}{l}\text { Kazan State Agrarian } \\
\text { University }\end{array}$ & $26.69 / 9$ & $26.32 / 7$ & $26.22 / 7$ & $26.23 / 7$ & $22.23 / 7$ & 7 \\
\hline
\end{tabular}




\begin{tabular}{|c|c|c|c|c|c|c|}
\hline High school & 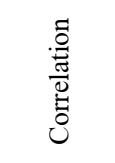 & 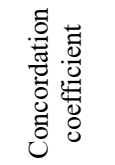 & 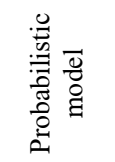 & 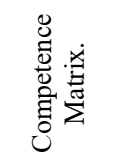 & 离. & 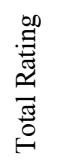 \\
\hline $\begin{array}{l}\text { Novosibirsk State Agrarian } \\
\text { University }\end{array}$ & $28.11 / 7$ & $25.91 / 8$ & $26.12 / 8$ & $25.89 / 8$ & $21.89 / 8$ & 8 \\
\hline $\begin{array}{l}\text { Saratov State Agrarian } \\
\text { University }\end{array}$ & $27.59 / 8$ & $25.61 / 9$ & $25.69 / 9$ & $25.58 / 9$ & $21,69 / 9$ & 9 \\
\hline $\begin{array}{l}\text { Volgograd State Agrarian } \\
\text { University }\end{array}$ & $25.71 / 10$ & $24.89 / 10$ & $25.21 / 10$ & $24.89 / 10$ & $21,01 / 10$ & 10 \\
\hline $\begin{array}{l}\text { Vyatka State Agrarian } \\
\text { University }\end{array}$ & $25.31 / 11$ & $24.41 / 11$ & $24.29 / 11$ & $24.53 / 11$ & $20.25 / 11$ & 11 \\
\hline $\begin{array}{l}\text { Vologda State Milk Industry } \\
\text { Academy }\end{array}$ & $24.71 / 13$ & $23.79 / 12$ & $23.79 / 12$ & $23.87 / 12$ & $19.33 / 12$ & 12 \\
\hline $\begin{array}{l}\text { Bryansk State Agrarian } \\
\text { University }\end{array}$ & $23.29 / 14$ & $22.61 / 13$ & $22.66 / 13$ & $22.69 / 13$ & $18.89 / 13$ & 13 \\
\hline $\begin{array}{l}\text { Velikie Luki State } \\
\text { Agricultural Academy }\end{array}$ & $22.41 / 15$ & $22.41 / 14$ & $22.39 / 14$ & $22.49 / 14$ & $18.34 / 14$ & 14 \\
\hline $\begin{array}{l}\text { Michurinsky State Agrarian } \\
\text { University }\end{array}$ & $25.11 / 12$ & $22.21 / 15$ & $22.21 / 15$ & $22.42 / 15$ & $17.89 / 15$ & 15 \\
\hline $\begin{array}{l}\text { Penza State Agricultural } \\
\text { Academy }\end{array}$ & $21,81 / 17$ & $21.91 / 16$ & $21.89 / 16$ & $22.11 / 16$ & $17.69 / 16$ & 16 \\
\hline $\begin{array}{l}\text { Buryat State Agricultural } \\
\text { Academy }\end{array}$ & $21.22 / 18$ & $21.81 / 17$ & $21.79 / 17$ & $21.89 / 17$ & $17.48 / 17$ & 17 \\
\hline $\begin{array}{l}\text { Perm State Agricultural } \\
\text { Academy }\end{array}$ & $21.81 / 16$ & $21.41 / 18$ & $21.65 / 18$ & $21.72 / 18$ & $17.31 / 18$ & 18 \\
\hline $\begin{array}{l}\text { Bashkir State Agrarian } \\
\text { University }\end{array}$ & $20.32 / 24$ & $21.21 / 19$ & $21.22 / 19$ & $21.33 / 19$ & $16.78 / 19$ & 19 \\
\hline $\begin{array}{l}\text { Saint Petersburg State } \\
\text { Agrarian University }\end{array}$ & $19.91 / 25$ & $21.11 / 20$ & $21.20 / 20$ & $21.19 / 20$ & $16.45 / 20$ & 20 \\
\hline $\begin{array}{l}\text { Kursk State Agricultural } \\
\text { Academy }\end{array}$ & $20.78 / 20$ & $21.09 / 21$ & $21.00 / 21$ & $21.14 / 21$ & $15.89 / 21$ & 21 \\
\hline $\begin{array}{l}\text { Nizhny Novgorod State } \\
\text { Agricultural Academy }\end{array}$ & $20.83 / 22$ & $20.89 / 22$ & $20.95 / 22$ & $21.01 / 22$ & $15.11 / 22$ & 22 \\
\hline $\begin{array}{l}\text { Chuvash State Agricultural } \\
\text { Academy }\end{array}$ & $20.81 / 21$ & $20.79 / 23$ & $20.90 / 23$ & $20.79 / 23$ & $15.49 / 23$ & 23 \\
\hline $\begin{array}{l}\text { Omsk State Agrarian } \\
\text { University }\end{array}$ & $21.11 / 19$ & $20.59 / 24$ & $20.55 / 24$ & $20.42 / 24$ & $15.29 / 24$ & 24 \\
\hline $\begin{array}{l}\text { Stavropol State Agrarian } \\
\text { University }\end{array}$ & $17.62 / 35$ & $20.32 / 25$ & $20.23 / 25$ & $20.33 / 25$ & $14.58 / 25$ & 25 \\
\hline $\begin{array}{l}\text { Altai State Agrarian } \\
\text { University }\end{array}$ & $20.42 / 23$ & $19.69 / 26$ & $19.79 / 26$ & $19.89 / 26$ & $14.43 / 26$ & 26 \\
\hline $\begin{array}{l}\text { Donskoy State Agrarian } \\
\text { University }\end{array}$ & $18.31 / 30$ & $19.49 / 27$ & $19.59 / 27$ & $19.56 / 27$ & $14.22 / 27$ & 27 \\
\hline $\begin{array}{l}\text { Moscow Veterinary and } \\
\text { Biotech Academy }\end{array}$ & $19.11 / 29$ & $19.21 / 28$ & $19.32 / 28$ & $19.22 / 28$ & $14.21 / 28$ & 28 \\
\hline $\begin{array}{l}\text { Irkutsk State Agrarian } \\
\text { University }\end{array}$ & $19.23 / 28$ & $18.81 / 29$ & $18.43 / 29$ & $18.78 / 29$ & $14.11 / 29$ & 29 \\
\hline $\begin{array}{l}\text { Kurgan State Agricultural } \\
\text { Academy }\end{array}$ & $19.28 / 27$ & $18.80 / 30$ & $18.79 / 30$ & $18.77 / 30$ & $13.79 / 30$ & 30 \\
\hline $\begin{array}{l}\text { Ulyanovsk State Agricultural } \\
\text { Academy }\end{array}$ & $15.79 / 38$ & $17.89 / 31$ & $18.27 / 31$ & $18.11 / 31$ & $13.58 / 31$ & 31 \\
\hline $\begin{array}{l}\text { Orenburg State Agrarian } \\
\text { University }\end{array}$ & $19.44 / 26$ & $17.79 / 32$ & $17.89 / 32$ & $17.88 / 32$ & $13.47 / 32$ & 32 \\
\hline $\begin{array}{l}\text { Samara State Agricultural } \\
\text { Academy }\end{array}$ & $17.62 / 34$ & $17.61 / 33$ & $17.79 / 33$ & $17.69 / 33$ & $13.34 / 33$ & 33 \\
\hline $\begin{array}{l}\text { Yaroslavl State Agricultural } \\
\text { Academy }\end{array}$ & $17.73 / 33$ & $17.49 / 34$ & $17.46 / 34$ & $17.49 / 34$ & $12.89 / 34$ & 34 \\
\hline
\end{tabular}




\begin{tabular}{|c|c|c|c|c|c|c|}
\hline High school & 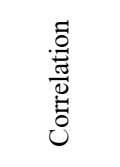 & 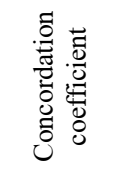 & 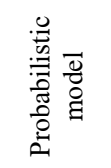 & 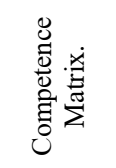 & 志 & 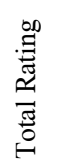 \\
\hline $\begin{array}{l}\text { Primorskaya State } \\
\text { Agricultural Academy }\end{array}$ & $17.89 / 31$ & $17.41 / 35$ & $17.29 / 35$ & $17.39 / 35$ & $12.76 / 35$ & 35 \\
\hline $\begin{array}{l}\text { Far East State Agrarian } \\
\text { University }\end{array}$ & $16.21 / 37$ & $17.21 / 36$ & $17.15 / 36$ & $17.29 / 36$ & $12.56 / 36$ & 36 \\
\hline State University of Land Use & $15.59 / 40$ & $17.12 / 37$ & $17.09 / 37$ & $17.23 / 37$ & $12.43 / 37$ & 37 \\
\hline $\begin{array}{l}\text { Ryazan State } \\
\text { Agrotechnological University }\end{array}$ & $17.77 / 32$ & $16.99 / 38$ & $17.05 / 38$ & $17.21 / 38$ & $12.31 / 38$ & 38 \\
\hline $\begin{array}{l}\text { Yakutsk State Agricultural } \\
\text { Academy }\end{array}$ & $16.11 / 36$ & $16.89 / 39$ & $17.03 / 39$ & $16.89 / 40$ & $12.03 / 39$ & 39 \\
\hline Ural State Agrarian University & $15.61 / 41$ & $16.81 / 40$ & $16.69 / 41$ & $17.09 / 39$ & $11.89 / 40$ & 40 \\
\hline $\begin{array}{l}\text { Ivanovo State Agricultural } \\
\text { Academy }\end{array}$ & $15.51 / 42$ & $16.59 / 41$ & $16.79 / 40$ & $16.67 / 41$ & $11.76 / 41$ & 41 \\
\hline $\begin{array}{l}\text { Kostroma State Agricultural } \\
\text { Academy }\end{array}$ & $15.71 / 39$ & $16.21 / 42$ & $16.43 / 42$ & $16.32 / 42$ & $11.34 / 42$ & 42 \\
\hline $\begin{array}{l}\text { Voronezh State Agrarian } \\
\text { University }\end{array}$ & $15.09 / 44$ & $15.79 / 43$ & $16.22 / 43$ & $16.21 / 43$ & $11.29 / 43$ & 43 \\
\hline $\begin{array}{l}\text { South Ural State Agrarian } \\
\text { University }\end{array}$ & $15.31 / 43$ & $15.69 / 44$ & $16.11 / 44$ & $15.56 / 44$ & $11.19 / 44$ & 44 \\
\hline $\begin{array}{l}\text { Izhevsk State Agricultural } \\
\text { Academy }\end{array}$ & $14.99 / 45$ & $14.88 / 45$ & $15.78 / 45$ & $15.45 / 45$ & $11.05 / 45$ & 45 \\
\hline $\begin{array}{l}\text { State Agrarian University } \\
\text { Northern Trans-Urals }\end{array}$ & $14.69 / 46$ & $14.87 / 46$ & $15.24 / 46$ & $14.79 / 46$ & $10.79 / 46$ & 46 \\
\hline $\begin{array}{l}\text { St. Petersburg State Academy } \\
\text { of Veterinary Medicine }\end{array}$ & $10.79 / 50$ & $14.77 / 47$ & $14.89 / 47$ & $14.69 / 47$ & $9.79 / 47$ & 47 \\
\hline $\begin{array}{l}\text { Russian State Agrarian } \\
\text { Correspondence University }\end{array}$ & $12.61 / 48$ & $14.33 / 48$ & $14.54 / 48$ & $14.57 / 48$ & $9.45 / 48$ & 48 \\
\hline $\begin{array}{l}\text { Kazan State Academy of } \\
\text { Veterinary Medicine }\end{array}$ & $13.81 / 47$ & $14.19 / 49$ & $14.52 / 49$ & $14.43 / 49$ & $9.39 / 49$ & 49 \\
\hline $\begin{array}{l}\text { Kabardino-Balkarian State } \\
\text { Agrarian University }\end{array}$ & $11.51 / 49$ & $12.08 / 50$ & $12.39 / 50$ & $12.39 / 50$ & $9.32 / 50$ & 50 \\
\hline $\begin{array}{l}\text { Gorsky State Agrarian } \\
\text { University }\end{array}$ & $8.21 / 52$ & $11.78 / 51$ & $11.89 / 51$ & $11.77 / 51$ & $8.78 / 51$ & 51 \\
\hline $\begin{array}{l}\text { Smolensk State Agricultural } \\
\text { Academy }\end{array}$ & $8.41 / 51$ & $10.87 / 52$ & $11.34 / 52$ & $10.69 / 52$ & $7.65 / 52$ & 52 \\
\hline $\begin{array}{l}\text { Tver State Agricultural } \\
\text { Academy }\end{array}$ & $7.41 / 53$ & $9.26 / 53$ & $9.43 / 53$ & $9.76 / 53$ & $5.89 / 53$ & 53 \\
\hline $\begin{array}{l}\text { Dagestan State Agrarian } \\
\text { University }\end{array}$ & $5.59 / 54$ & $5.59 / 54$ & $5.34 / 54$ & $5.45 / 54$ & $4.45 / 54$ & 54 \\
\hline
\end{tabular}

\section{Conclusion}

Research of the content of the websites of universities showed a very low completeness of filling the websites with information. So, the sites have only about $55.4 \%$ of all the necessary data. And the completeness of scientific information is only $18.3 \%$, which once again shows the underestimation of the scientific activities of educational institutions by the state. As a result, the overall assessments (tab. 11) of the human capital of no one, even the best university, do not reach the level of $40 \%$. For example, the Kuban State Agrarian Universtiy has an overall rating of $39.09 \%$. 
Table 2. General estimates (in\%) of $\mathrm{HC}$ on the efficiency of using regional INOR and ratings of agricultural universities.

\begin{tabular}{|c|c|c|c|c|c|}
\hline High School & Grade & Rating & High School & Grade & Rating \\
\hline $\begin{array}{l}\text { Kuban State Agrarian } \\
\text { University }\end{array}$ & 39.09 & 1 & $\begin{array}{l}\text { Buryat State Agricultural } \\
\text { Academy }\end{array}$ & 22.48 & 28 \\
\hline $\begin{array}{l}\text { Oryol State Agrarian } \\
\text { University }\end{array}$ & 38.31 & 2 & $\begin{array}{l}\text { Altai State Agrarian } \\
\text { University }\end{array}$ & 22.19 & 29 \\
\hline $\begin{array}{l}\text { RSAU-Moscow } \\
\text { Agricultural Academy }\end{array}$ & 32.49 & 3 & $\begin{array}{l}\text { Ivanovo State Agricultural } \\
\text { Academy }\end{array}$ & 21.29 & 30 \\
\hline $\begin{array}{l}\text { Krasnoyarsk State Agrarian } \\
\text { University }\end{array}$ & 30.79 & 4 & $\begin{array}{l}\text { Kursk State Agricultural } \\
\text { Academy }\end{array}$ & 21.21 & 31 \\
\hline $\begin{array}{l}\text { Novosibirsk State Agrarian } \\
\text { University }\end{array}$ & 30.55 & 5 & $\begin{array}{l}\text { Kurgan State Agricultural } \\
\text { Academy }\end{array}$ & 21.11 & 32 \\
\hline $\begin{array}{l}\text { Kemerovo State Agrarian } \\
\text { University }\end{array}$ & 30.26 & 6 & State University of Land Use & 20.79 & 33 \\
\hline $\begin{array}{l}\text { Bryansk State Agrarian } \\
\text { University }\end{array}$ & 29.37 & 7 & $\begin{array}{l}\text { Izhevsk State Agricultural } \\
\text { Academy }\end{array}$ & 20.66 & 34 \\
\hline $\begin{array}{l}\text { Belgorod State Agrarian } \\
\text { University }\end{array}$ & 29.23 & 8 & $\begin{array}{l}\text { Primorskaya State } \\
\text { Agricultural Academy }\end{array}$ & 20.28 & 35 \\
\hline $\begin{array}{l}\text { Kazan State Agrarian } \\
\text { University }\end{array}$ & 28.31 & 9 & $\begin{array}{l}\text { Samara State Agricultural } \\
\text { Academy }\end{array}$ & 19.69 & 36 \\
\hline $\begin{array}{l}\text { Saratov State Agrarian } \\
\text { University }\end{array}$ & 27.51 & 10 & $\begin{array}{l}\text { Orenburg State Agrarian } \\
\text { University }\end{array}$ & 19.59 & 37 \\
\hline $\begin{array}{l}\text { Moscow Veterinary and } \\
\text { Biotech Academy }\end{array}$ & 26.39 & 11 & $\begin{array}{l}\text { Yaroslavl State Agricultural } \\
\text { Academy }\end{array}$ & 19.49 & 38 \\
\hline $\begin{array}{l}\text { Penza State Agricultural } \\
\text { Academy }\end{array}$ & 26.28 & 12 & $\begin{array}{l}\text { Voronezh State Agrarian } \\
\text { University }\end{array}$ & 19.12 & 39 \\
\hline $\begin{array}{l}\text { Volgograd State Agrarian } \\
\text { University }\end{array}$ & 26.21 & 13 & $\begin{array}{l}\text { Ryazan State } \\
\text { Agrotechnological University }\end{array}$ & 19.11 & 40 \\
\hline $\begin{array}{l}\text { Bashkir State Agrarian } \\
\text { University }\end{array}$ & 25.57 & 14 & $\begin{array}{l}\text { Far Eastern State Agrarian } \\
\text { University }\end{array}$ & 18.89 & 41 \\
\hline $\begin{array}{l}\text { St. Petersburg State } \\
\text { Agrarian University }\end{array}$ & 25.22 & 15 & $\begin{array}{l}\text { Irkutsk State Agrarian } \\
\text { University }\end{array}$ & 18.79 & 42 \\
\hline $\begin{array}{l}\text { Vyatka State Agrarian } \\
\text { University }\end{array}$ & 24.59 & 16 & $\begin{array}{l}\text { Kazan State Academy of } \\
\text { Veterinary Medicine }\end{array}$ & 18.69 & 43 \\
\hline $\begin{array}{l}\text { Omsk State Agrarian } \\
\text { University }\end{array}$ & 24.49 & 17 & $\begin{array}{l}\text { St. Petersburg State Academy } \\
\text { of Veterinary Medicine }\end{array}$ & 18.49 & 44 \\
\hline $\begin{array}{l}\text { Vologda State Milk } \\
\text { Industry Academy }\end{array}$ & 24.42 & 18 & South Ural GAU & 18.38 & 45 \\
\hline $\begin{array}{l}\text { Don State Agrarian } \\
\text { University }\end{array}$ & 24.31 & 19 & $\begin{array}{l}\text { Kabardino-Balkarian State } \\
\text { Agrarian University }\end{array}$ & 17.55 & 46 \\
\hline $\begin{array}{l}\text { Michurinsky State Agrarian } \\
\text { University }\end{array}$ & 24.19 & 20 & $\begin{array}{l}\text { Yakutsk State Agricultural } \\
\text { Academy }\end{array}$ & 17.19 & 47 \\
\hline $\begin{array}{l}\text { Stavropol State Agrarian } \\
\text { University }\end{array}$ & 24.12 & 21 & $\begin{array}{l}\text { Kostroma State Agricultural } \\
\text { Academy }\end{array}$ & 16.67 & 48 \\
\hline $\begin{array}{l}\text { Ural State Agrarian } \\
\text { University }\end{array}$ & 23.79 & 22 & $\begin{array}{l}\text { State Agrarian University of } \\
\text { the Northern Trans-Urals }\end{array}$ & 16.59 & 49 \\
\hline $\begin{array}{l}\text { Velikie Luki State } \\
\text { Agricultural Academy }\end{array}$ & 23.69 & 23 & $\begin{array}{l}\text { Gorsky State Agrarian } \\
\text { University }\end{array}$ & 15.89 & 50 \\
\hline $\begin{array}{l}\text { Nizhny Novgorod State } \\
\text { Agricultural Academy }\end{array}$ & 23.49 & 24 & $\begin{array}{l}\text { Russian State Agrarian } \\
\text { Correspondence University }\end{array}$ & 15.52 & 51 \\
\hline $\begin{array}{l}\text { Chuvash State Agricultural } \\
\text { Academy }\end{array}$ & 23.31 & 25 & $\begin{array}{l}\text { Smolensk State Agricultural } \\
\text { Academy }\end{array}$ & 15.41 & 52 \\
\hline $\begin{array}{l}\text { Ulyanovsk State } \\
\text { Agricultural Academy }\end{array}$ & 23.21 & 26 & $\begin{array}{l}\text { Dagestan State Agrarian } \\
\text { University }\end{array}$ & 12.43 & 53 \\
\hline $\begin{array}{l}\text { Perm State Agricultural } \\
\text { Academy }\end{array}$ & 22.79 & 27 & $\begin{array}{l}\text { Tver State Agricultural } \\
\text { Academy }\end{array}$ & 5.78 & 54 \\
\hline
\end{tabular}


Ignoring the possibilities of the formation of EIIPNOR by the state has led to the fact that universities do not particularly care about filling sites with scientific and educational resources, following only the instructions of the Ministry of Education and Science of the Russian Federation and Rosobrnadzor. The presentation of these resources on the sites is supported only by the enthusiasm of individual performers. Even if some individual types of INOR are present on the websites, the absence of a DBMS in the development environment leads to the fact that the number of INOR types at the university level does not coincide, and significantly, with the number at the faculty and department levels. Based on the requirements of the Ministry of Education and Science and Rosobrnadzor, the management of universities believes that the main audience of their websites are employees of supervisory agencies, applicants and students, while completely ignoring the needs of commodity producers, scientists, management of companies and the population.

To demonstrate the low information content (quality) of INOR in tab. 2 and tab. 3 presents the relevant information at the university level.

Table 3. Quality and quantity of INOR on High School sites.

\begin{tabular}{|l|c|c|c|c|c|}
\hline $\begin{array}{c}\text { Types of \% } \\
\text { of sites with } \\
\text { the INOR }\end{array}$ & $\begin{array}{r}\% \\
\text { of sites with } \\
\text { the } \\
\text { INOR }\end{array}$ & $\begin{array}{c}\text { Unordered } \\
\text { list }\end{array}$ & $\begin{array}{l}\text { Digital } \\
\text { catalogue }\end{array}$ & $\begin{array}{l}\text { Unordered } \\
\text { full-size } \\
\text { view }\end{array}$ & $\begin{array}{l}\text { Streamlined } \\
\text { full-length } \\
\text { electronic } \\
\text { presentation }\end{array}$ \\
\hline Development & 85 & 3684 & 391 & 337 & 248 \\
\hline Publications & 89 & 18649 & 408 & 344 & 0 \\
\hline Database & 11 & 530 & 45 & 0 & 0 \\
\hline Software & 2 & 828 & 2 & 25 & 0 \\
\hline $\begin{array}{l}\text { Distance } \\
\text { learning }\end{array}$ & 12 & 1195 & 0 & 0 & 3 \\
\hline Consultants & 25 & 216 & 43 & 9 & 0 \\
\hline $\begin{array}{l}\text { Regulatory } \\
\text { information }\end{array}$ & 55 & 65 & 0 & 328 & 19 \\
\hline
\end{tabular}

This year marks the 100th anniversary of the outstanding Soviet scientist A.I. Kitov, who together with Academician V.M. Glushkov, back in the 60s of the last century, proposed to the leadership of the USSR a project of the National Automated System for the Collection and Processing of Information for Accounting, Planning and Management of the National Economy in the USSR (OGAS) [10]. OGAS was intended to carry out operational accounting and control over any object in the country, so that in the future it was possible to effectively plan and forecast the development of society, including human capital.

The rejection of this project led to the emergence of a huge number of heterogeneous and functionally incompatible information systems at most organizations in the country. The ongoing trend thus set will constrain the quality implementation of the Digital Economy Program and lead to a decrease in human capital.

The Common Information Internet Space of the country's digital interaction considered in the work is the implementation of the OGAS project in the digital economy. Why, then, the ideas of the OGAS do not find support from the country's leadership, although their implementation promises multiple efficiency in the implementation of the Digital Economy Program? Why, within the framework of this Program, the country continues to apply the methods and means of task-oriented design of information systems (IS), which developed in 
previous times and are more familiar to many leaders and specialists, following the words of W. Churchill "Generals always start a war with the old methods"?

The reason for this was once stated by Zh. Alferov: "The main problem of Russian science is its lack of demand by the economy and society". Calculations according to the presented method for assessing human capital confirmed this conclusion, and in 2020 . confirmed by the Accounts Chamber.

The proposed EIIPNOR digital platform, organically included in the Unified Internet Information Space of the country's digital interaction, will be a powerful tool for improving and increasing the quality of human capital, increasing the social welfare of society, and transferring the most effective innovative solutions to the economy.

The reported study was funded by RFBR, project number 19-29-07125 "Modeling scenarios for the development of the human capital in Russia and the development of methodological tools for assessing its impact on economic growth, social well-being and development of Russian society in the context of digitalization of the economy and increasing national competitiveness".

\section{References}

1. D.V. Gonin, Methodology for assessing human capital in the field of public administration: a modern approach [Electronic resource] URL: https://sziu.ranepa.ru/images/nauka/UK_DOI/5_17/Gonin_5_17.pdf (date of access 03.03.2020)

2. Russia ranked 39th out of 70 countries in terms of English proficiency, URL: https://www.rbc.ru/economics/03/11/2015/563866969a79474acfd69663 (access date $12 / 16 / 2019)$

3. Only $14 \%$ of Russian candidates and doctors of sciences are fluent in English, URL: https://philologist.livejournal.com/10604467.html (date of access 12/16/2019)

4. V.I. Medennikov, L.G. Muratova, S.G. Salnikov, Models and methods of forming a single information Internet space of agricultural knowledge (GUZ Publishing House, 2014)

5. F.I. Ereshko, V.I. Medennikov, S.G. Salnikov, Designing a single informational Internet space for the country, Business within the law, Econ. and legal j. 6, 184-187 (2016)

6. V.I. Medennikov, S.G. Salnikov, L.G. Muratova et al. Methods for assessing the effectiveness of the use of information scientific and educational resources (Analyst, 2017)

7. D.L. Georgievsky, Educational content as a factor in increasing the competitiveness of the university, Collection of reports of the participants of the International Scientific Conference dedicated to the 90th anniversary of S.P. Kapitsa "Human Capital in the Format of the Digital Economy" (Editorial and Publishing House of the Russian New University, 2018) URL: https://minobrnauki.gov.ru/ru/press-center/card/?id_4=2241

8. M.Yu. Guzaeva, Using information resources of science and education to improve the efficiency of the implementation of new forms of education, http://pedsovet.su/publ/1641-0-1048/ (date of access: 05/30/2016)

9. Yu.A. Korchagin, I.P. Malichenko, Investment and investment analysis: a textbook (Rostov-on-Don, Phoenix, 2010)

10. G. V. Sirotkin, System analysis of the factors of the quality of education at the university, Caspian Journal: Management and High Technologies 2 (22), 109-118 (2013) 